\title{
Impact of Discovery-Based Learning Method on Senior Secondary School Physics
}

\author{
Anyafulude Joy (Ph.D) \\ Department of Education Foundation, Enugu state University of Science and Technology, Nigeria.
}

\begin{abstract}
The purpose of the study is to ascertain the impact of discovery-based learning method on teaching and learning of physics in secondary schools in Awgu Education Zone. Two research questions and two hypotheses were posed to guide the study. The study adopted a descriptive survey design. A sample size of 490 respondents made up of 291 male and 199 female teachers were drawn using stratified random sampling techniques from four senior secondary schools in Awgu Education Zone. The instrument used for data collection was a 10 - item questionnaire. The instrument had face validity and reliability co-efficient of .77 obtained using Cronbach Alpha formular. Mean statistic was used to answer the research questions while the hypotheses were tested at .05 level of significance using t-test statistic. The result of data analysis show that; discovery-based learning method has helped to a great extent in effective teaching and learning of Physics. Also, discoverybased learning method has promoted research in Physics. The respondents classified by gender did not differ on the extent to which discovery-based learning method helped in effective teaching and learning, improved students' knowledge and promoted research in Physics. Conclusion and recommendations were equally highlighted.
\end{abstract}

Key words: Discovery-based, effectiveness, learning, Physics, Impact.

\section{Introduction}

One of the main principles of science and technology is to teach students with notion of discovering, engaging in critical thinking, questioning and developing problem solving skills. The curriculum for science and technology therefore should be developed to educate science - literate students to enable them inquire and solve problems facing them.

Science teaching is based on the understanding of natural phenomena and the nature of science requires inquiring and discovering. [1] cited in [2] stated that learning happens by discovering, which prioritizes reflection, thinking, experimenting, and exploring. Discovery learning approach to education is more closely aligned with constructivist concepts of exploration, discovering and invention [3] Constructivist theory is the basis for discovery learning. Under both constructivism and discovery learning, educators subscribe to the idea that "knowledge cannot be transferred from one person to another" [4] Instead, a student needs to experience an event in order to make it truly meaningful. In a constructivist classroom, the role of the teacher is less defined. The teacher is no longer the focal point of the classroom. Instead, the suppose instructor is now seen as a facilitator, mentor, coach, or consultant additionally, the role and expectations of the students are transformed. Interest should not be on the content level a student manages to retain, rather on the manner in which the students learn, or constructs knowledge.

People who use self discovery in learning turn out to be more self-confident. Discovery is a way from the unknown to the known by the learners themselves [5] The active participation of the learner in the learning process is called discovery learning [6] In discovery learning, students construct knowledge based on new information and data collected are used by them in an explorative learning environment [7] .

Physics as a science subject demands a lot of abstract thinking for its understanding. It requires the learner to store and manipulate many bits of information in memory. Most students find it difficult to solve problems in physics because of the abstract nature of the subject, and often the instructional methods used are obsolete. This can result to poor academic achievement and retention on the part of the students. Physics is a subject that grew up with civilization as man's quantitative need increased. Physics as a unique subject promotes the acquisition of specialized science skills and knowledge. It arose out of practical problems and mans need to solve these problems. Its teaching is to bring about scientific thinking in students.

Investigations reveal that secondary school students' achievement in Physics in both internal and external examinations have been consistently poor [8] and [9.] A number of factors could contribute to the students' poor achievement in Physics in the senior secondary school certificate examination. Researchers [10], [11] and [12] have variously identified such factors as students' poor academic background, insufficient qualified teachers, lack of motivation on the part of the teachers and their students and inappropriate teaching methods. The need to foster students' achievement in Physics has given rise to innovative strategies that provide room for students' active participation in the lesson. Teaching methods should facilitate the learning 
process for both genders. Teachers ought to be mindful that unless the teaching method matches the different learning styles observed to be the dominant modality for each gender, students may not comprehend [13]

Discovery learning unites students and content simultaneously. Additionally, scientists will agree that discovery-based learning replicates a true scientific experience for students [4] and [15].

As a result of the foregoing the researcher got motivated to empirically ascertain the impact of discovery-based learning method on teaching and learning of physics in secondary schools in Awgu Education zone of Enugu State.

\subsection{Purpose of the Study}

The study tried to:

1. Ascertain the impact of discovery-based learning method on teaching and learning of Physics in secondary schools in Awgu Education zone.

2. Determine the extent to which discovery-based learning method promotes research in Physics subject.

1.2. Research Questions 1

The following research questions guided the study:

(1) To what extent has discovery-based learning method helped in effective teaching and learning of Physics?

(2) To what extent has discovery-based learning method promoted research in Physics?

\subsection{Hypotheses}

The following hypotheses were tested at .05 level of significance.

1. There is no significant difference between the mean scores of male and female teachers on the extent to which discovery-based learning method helped in effective teaching and learning of Physics.

2. There is no significant difference between the mean scores of male and female teachers on the extent to which discovery-based learning method promoted research in Physics.

\section{Method}

The study adopted descriptive survey design. The population for the study comprised all the 4,635 teachers in the 23 public secondary schools in Awgu Education zone. A stratified random sampling was used to draw a sample of 490 respondents made up of 291 male and 199 female teachers.

The instrument for data collection was a 10 - item questionnaire. The instrument was face validated by three research experts, two in Educational Psychology and one in Measurement and Evaluation, all from Faculty of Education in Enugu State University of Science and Technology. The reliability of the instruments was determined using Cronbach Alpha and a reliability coefficient of 0.77 obtained. The researcher administered 490 copies of questionnaire with the help of three research assistants. All the 490 copies of questionnaire were correctly filled giving a return rate of $100 \%$. Regarding the decision rule, any questionnaire item with a mean of 2.50 or above was interpreted to mean high extent response for such item while a mean score below 2.50 indicates a low extent response for the items. Mean Statistic was used to answer research questions while hypotheses were tested at 0.05 level of significance using t-test statistic. The t-test was appropriate because it is capable of handling both large and small number samples.

\section{Results}

3.1 Research Question 1: To what extent is the discovery-based learning method effective in teaching and learning of Physics?

Table 1: Mean Response on the Extent to which Discovery-Based Learning Method is Effective in the teaching and Learning of Physics.

\begin{tabular}{|c|c|c|c|c|c|c|}
\hline $\mathrm{S} / \mathrm{N}$ & Items & VGE & $\begin{array}{l}\text { GE } \\
3\end{array}$ & $\begin{array}{l}\text { LE } \\
2\end{array}$ & $\begin{array}{l}\text { VLE } \\
1\end{array}$ & $\bar{X}$ \\
\hline 1 & $\begin{array}{l}\text { Discovery-based Learning method encourages students to be } \\
\text { constructive in learning of Physics concepts. }\end{array}$ & 201 & 142 & 81 & 66 & 2.97 \\
\hline 2 & $\begin{array}{l}\text { Discovery-based Learning method facilitates students' critical } \\
\text { thinking in learning Physics subject. }\end{array}$ & 198 & 138 & 95 & 59 & 2.96 \\
\hline 3 & It enhances students' skill of exploration and invention in Physics & 240 & 120 & 66 & 64 & 3.09 \\
\hline 4 & $\begin{array}{l}\text { Discovery-based Learning method helps students improve their } \\
\text { problem solving skills in Physics subject }\end{array}$ & 187 & 120 & 98 & 85 & 2.83 \\
\hline 5 & $\begin{array}{l}\text { Discovery-based Learning method engages students in effective } \\
\text { inquiry and discovery in learning Physics }\end{array}$ & 150 & 180 & 86 & 74 & 2.82 \\
\hline \multicolumn{2}{|c|}{$\mathrm{N}=490$} & & & & & \\
\hline
\end{tabular}


All items above show that the discovery-based learning method is effective to a great extent in teaching and learning of Physics with grand mean score of 3.93.

\subsection{Research Question 2}

To what extent has discovery-based learning method promoted research in Physics?

Table 2: Mean Response on Extent to which Discovery-Based Learning Method Promote Research in Physics Subject.

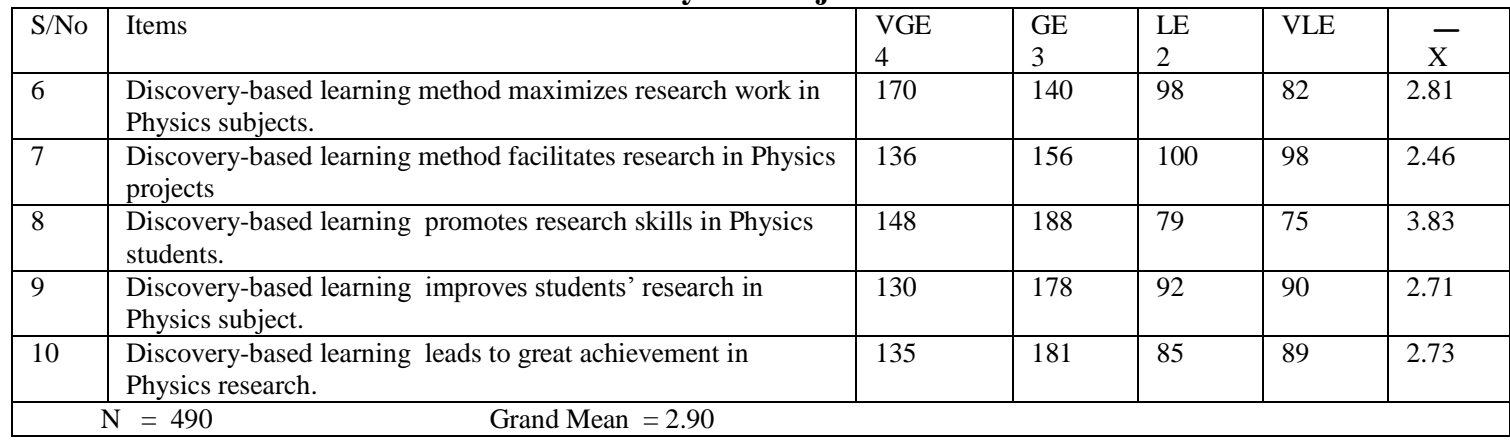

Grand mean of 2.90 which indicates great extent reveals that discovery-based learning promotes research in Physics subject.

\subsection{Hypotheses}

$\mathrm{Ho}_{1}$ : There is no significant difference in the mean scores of male and female teachers on the extent to which discovery-based learning method helps in effective teaching and learning of Physics in secondary schools in Agwu Education Zone.

Table 3: T-test Mean Rating of Male and Female Teachers on the Extent to which Discovery-Based Learning Method helps in Effective Teaching and Learning of Physics in secondary Schools in Awgu Education Zone.

\begin{tabular}{|c|c|c|c|c|c|c|c|}
\hline Respondents & $\mathrm{N}$ & $\bar{X}$ & SD & $\mathrm{d} / \mathrm{f}$ & t-cal. & t-crit. & Decision \\
\hline Male Teachers & 291 & 2.98 & 0.77 & \multirow[b]{2}{*}{488} & \multirow[b]{2}{*}{0.68} & \multirow[b]{2}{*}{1.96} & \multirow[b]{2}{*}{ Ns } \\
\hline Female Teachers & 199 & 2.76 & 0.82 & & & & \\
\hline
\end{tabular}

TABLE 3 revealed that the $\mathrm{t}$-calculated is 0.68 , while the $\mathrm{t}$-critical value is 1.96 . Since 0.68 is less than 1.96 at .05 level of significance, thus, the null hypothesis is not rejected. This indicates that there is no significant difference between the mean scores of male and female teachers on the extent to which discoverybased learning method is effective in the teaching and learning of Physics by SS II students.

$\mathrm{Ho}_{2}$ : There is no significant difference in the mean scores of male and female teachers on the extent to which discovery-based learning method promotes research in Physics.

TABLE 4: T-test Mean Response of Male and Female Respondents on the Extent to Which DiscoveryBased Learning Method Promotes Research in Physics Subject.

\begin{tabular}{|l|l|l|l|l|l|l|l|}
\hline Respondent & $\mathrm{N}$ & $\mathrm{X}$ & $\mathrm{SD}$ & $\mathrm{d} / \mathrm{f}$ & $\mathrm{t}$-cal. & t-crit. & Decision \\
\hline Male Teacher & 291 & 2.91 & 0.71 & & & & \\
\\
Female Teacher & 199 & 2.84 & 0.76 & 488 & 0.45 & \multirow{2}{*}{1.96} & Ns \\
\hline
\end{tabular}

In TABLE 4 above, the t-calculated (0.45) is less than the t-critical (1.96) at .05 level of significance. Thus, the null hypothesis is not rejected indicating that gender is not a significant factor in the extent discoverybased learning method promotes research in Physics subject.

\section{Discussion}

The result of data analysis on TABLE I revealed that the use of discovery-based learning method is effective to a great extent in the teaching and learning of Physics. This result is in agreement with the findings of [16] who found out that discovery-based pedagogy works best in promoting meaningful learning when the learner strives to make sense of the presented materials by selecting relevant incoming information, organizing it into a coherent structure, and integrating it with other organized knowledge. Above is contrary to the view of both [17] and [18] who emphasized that because discovery learning relies on an extensive search through 
problem-solving space, the process taxes learners' limited working memory capacity and frequently does not lead to learning. In addition, learners need the ability to monitor their own processes of attention to relevant information [19]

From the result of data analysis on TABLE 2, it has been observed in this study that the use of discovery-based learning method promoted research to a great extent in Physics subject. Above statement supports that of [1] cited in [2] who emphasized that discovery-based learning encourages learners to be constructivists and that practice in discovery teaches the learner how best to acquire information to make it more available. Again, Bruner implied that the act of discovery teaches the learner how best to acquire information to make it more readily relevant and available. All assertions made above favour research work to the latter.[1] cited in [2] also warned that the learners' mind has to be prepared for discovery if it should favour research. Bruner claimed that discovery was more often the result of a learner gaining insights that transforms his/her knowledge base through new ways of organizing the previously learned information. Furthermore, the prepared mind for Bruner was one with experience in discovering itself. All these in one way or the other boasts research.

However, in TABLES 3 and 4, the results revealed that there were no significant differences in the mean response scores of male and female respondents on the extent discovery-based learning method is effective in teaching and learning Physics and on the extent discovery-based learning method promoted research in Physics. This showed that both male and female teachers have similar view regarding the use of discoverybased learning method in Physics subject. Apparently, both sexes noted equally the efficacy of discovery-based learning method in teaching Physics in senior secondary schools.

The following recommendations were made:-

\section{Recommendation}

(1) Seminars and workshops should be organized by secondary school teachers on other teaching/learning methods.

(2) Teachers are encouraged to use discovery-based learning method regularly as it enhances teaching and learning of secondary school subjects.

\section{Conclusion}

The following conclusions were made:-

(1) Discovery-based learning has helped to a great extent in effective teaching and learning of Physics.

(2) Discovery-based learning has promoted to great extent research in Physics.

(3) The respondents classified by gender did not differ on the extent to which discovery-based learning promoted research in Physics and improved student's knowledge in physics.

\section{References}

[1]. J.S. Bruner, The Act of Discovering Harvard Educational Review 31, 1961, 21-32.

[2]. F. Afolabi, The effects if Discovering-based and competitive learning strategies on academic performance of senior secondary school students in Physics. International Journal of Social and Management Sciences, 2(2), 2009, 4-10.

[3] D. Bok, Our Underachieving colleges: A candid look at how much students learn and why they should be learning more. Princeton, NJ Princeton University Press, 2006.

[4]. D. Domin, A review of Laboratory instruction styles. Journal of Chemical Education, 76, 1999, 1-5.

[5]. J.S. Bruner, Some elements of discovery. In L.S. Shulman, and E.R. Keislar, (Ed.), Learning by discovering: A critical appraisal. Chicago: Rand McNally 1966, 104-111.

[6]. J.S. Bruner, Toward a theory of Instruction. New York: W.W. Norton and Company, 1968.

[7]. T. De Jong, W.R. Van Joolingen, Discovering Learning with Computer simulations of conceptual doniains. Review of Educational Research, 68, 1998, 179-201.

[8]. Y. Kara, S.A. Ozgun-Coca, The Application of discovering learning and meaningful learning approaches in Mathematics classes: Two lesson plans on "the square of addition of two terms". Ikogretim Online 3 (1), 2004, 2-10.

[9]. N. Kipnis; Chance in Science: The discovering of electromagnetism by H.C. Oesrsted; Science \& Education, 14, $2005,1-28$.

[10]. G.A. Ajewole, Effects of Discovering and Expository Instructional Methods on the Attitude of Biology Students. Journal of Research in Science Teaching 28, 1998, 401-409.

[11]. L.R. Akudolu, Teaching language arts. Enugu: John Jacobs Classic Publishers, 2006

[12] D. Williams, Teaching of English Studies. Ibadan: Spectrum Books, 1999.

[13]. E.I. Adam, Teaching and Learning the Basic English Language skills in Enugu State Secondary schools. Unpublished Masters Dissertation: UNN, 2000.

[14] E.N. Okafor, A Comparative Study of the Effectiveness of communicative and electic approaches in English Language. Unpublished Ph.D. Thesis: Nnamdi Azikiwe University, Awka, 2005

[15]. L. Garrielle, A foucaution Approach to Academic Anxiety. American Educational Research Journal 35 (4) , $2008,73-83$.

[16]. M.A. Mastropieri, Differentiated curriculum enhancement in inclusive middle school science: Effects on classroom and highstakes tests 2006,. 130-137.

[17]. R.E. Mayer, Learning and Instruction: Upper Saddle River, N.J: Prentice Hall, 2003.

[18]. J. Sweller, Cognitive Load during problem solving: Effects on Learning. Cognitive Science, 12, $257-285$. doi:10/207/S/55/6709cag1202-4, 1988. 
[19]. B. Rittle-Johnson, Promoting transfer. Effects of Self- explanation and direct instruction. Child Development, 77, 1-15. doi 10.1111/j.1467-8624.2006.00852.x, 2006.

[20] R. Case, O. Kirshchner, The Development of Conceptual Structures In D. Kuhn \& R.S. Siegler (Eds.) Hand-book of Child Psychology: Cognition, Perception and Language (Vol. 2 pp. 745-800). New York. NY: Wiley, 2006. 